Jurnal Ekonomi dan Industri

e-ISSN: 2656-3169

Volume 22, No.1, Januari-April 2021

p- ISSN: 0853-5248

\title{
PENGARUH KOMPETENSI DAN MOTIVASI TERHADAP PRESTASI KERJA PT. MULTI PRATAMA INTERBUANA INDONESIA
}

\author{
Irwan Indriyanto *) \\ *) Dosen Program Studi Manajemen FE UNKRIS \\ Alamat: Kampus UNKRIS, Jatiwaringin Jakarta Timur \\ Email: indriyantoirwan@gmail.com
}

\begin{abstract}
To determine the effect of competence and motivation on work performance. This research is to analyze the causal relationship between competence and motivation on job performance. The data used are primary data by distributing questionnaires to employees of PT. Multi Pratama Interbuana Indonesia. The analysis method uses descriptive analysis and partially or simultaneous linear regression analysis. The sample used was 59 employees from a total population of 142 employees who were obtained using Slovin with a $10 \%$ annoyance level. The results showed that both partially and simultaneous there was a positive and significant influence on competence and motivation on employee performance.
\end{abstract}

Keywords: Competence, motivation and work performance

\section{PENDAHULUAN}

Penilaian prestasi kerja bertujuan untuk mengetahui kekuatan dan kelemahan karyawan, sehingga proses umpan balik sebagai motivator dapat berjalan dengan baik untuk memperbaiki kesalahan karyawan dalam bekerja dan penentuan alokasi reward yang sesuai dengan prestasi kerja masing-masing karyawan. Tujuan setiap perusahaan adalah mencapai prestasi kerja yang baik, sehingga dengan prestasi kerja karyawan yang tinggi diharapkan perusahaan akan mampu mencapai tujuan secara efektif. Prestasi kerja yang tinggi akan cenderung lebih berusaha untuk meraih sukses dari orang yang mempunyai prestasi kerja yang rendah. Faktor yang dapat mempengaruhi tingginya prestasi kerja karyawan di antaranya kompetensi kerja karyawan.

Kompetensi kerja merupakan suatu ketrampilan yang dimiliki oleh seseorang terhadap segala aspek pekerjaan yang akan dijalankan dan ketrampilan tersebut membuatnya merasa mampu untuk bisa mencapai rerbagai tujuan dalam pekerjaanya. Kompetensi mempunyai arti yang sama dengan kata kemampuan kecakapan atau keahlian. kompetensi dalam suatu situasi tidak dapat digunakan untuk memperkirakan kompetensi dalam situasi lain (Rosyadi dan Muwarti, 2002). Peran kompetensi sangat diperlukan dalam prestasi kerja karyawan. Karyawan yang mempunyai kompetensi kerja yang baik tentu akan mudah untuk melaksanakan semua tanggung jawab pekerjaan. Mampu membaca situasi dan permasalahan yang terjadi dalam pekerjaan serta dapat memberikan respon yang tepat dan memiliki penyesuaian diri yang baik dengan lingkungannya. Selain kompetensi yang dapat meningkatkan prestasi kerja karyawan adalah motivasi kerja karyawan.

Motivasi didefinisikan sebagai keadaan dalam pribadi seseorang yang mendorong keinginan individu untuk melaksanakan kegiatan-kegiatan untuk mencapai tujuan. Pemberian motivasi juga berarti memberikan kesempatan kepada karyawan untuk mampu mengembangkan kemampuan dan merupakan dorongan semaksimal mungkin karyawan untuk berproduksi. Pemberian motivasi berupa jaminan keselamatan kerja dan kesejahteraan 
Raryawan mampu mengembangkan kemampuan dan merupakan dorongan semaksimal mungkin karyawan untuk berprestasi.

Prestasi kerja diberi batasan sebagai kesuksesan seseorang di dalam melakukan pekerjaan sesuai dengan kekuatan dan kemampuan yang dimilikinya. Karyawan yang berprestasi berarti karyawan dalam pelaksanakan kerjanya dapat memberikan hasil yang baik, serta waktu yang ditentukan dan bermutu. Tingginya tingkat prestasi kerja karyawan dipengaruhi oleh dorongan yang disebabkan karena kemampuan yang dimiliki seorang karyawan merupakan potensi yang membutuhkan daya dorong.

Penurunan kompetensi karyawan, hal tersebut disebabkan oleh sistem kontrak menyebabkan seringnya pergantian karyawan sehingga banyak karyawan baru yang kealiannya terbatas dan terdapat beberapa karyawan asing yang menjadi staf ahli sehingga terdapat kesulitan komunikasi dengan karyawan yang lain. Namun berdasarkan wawancara dengan'salah satu remimpin perusahaan, untuk menghadapi masalah tersebut perusahaan telah melakukan kebijakan antara lain memberikan pelatihan-pelatihan, perubahan sistem kontrak menjadi karyawan tetap berdasarkan syarat-syarat tertentu dan memberikan motivasi yang berupa penghargaan kepada karyawan dalam bentuk pujian, hadiah, gaji yang menarik, bonus dan lain sebagainya. Perusahaan mengharapkan dengan adanya kebijakankebijakan tersebut prestasi kerja karyawan dapat meningkat.

\section{LANDASAN TEORI}

\section{Prestasi Kerja}

Kinerja atau prestasi kerja (performance) diberi batasan sebagai kesuksesan seseorang dalam melaksanakan suatu pekerjaan. Lebih tegas lagi Porter dan Lawyer menyatakan bahwa prestasi kerja adalah "successful role achievemenf yang diperoleh dari seorang dari perbuatannya (Foster, 2001). Prestasi kerja adalah hasil yang dicapai seseorang menurut ukuran yang berlaku untuk pekerjaan yang bersangkutan. Tingkat sejauh mana keberhasilan seseorang dalam menyelesaikan tugas pekerjaannya disebut "level of performance" (Vroom, 1991). Biasanya orang yang level of performancenya tinggi disebut orang yang produktif, dan sebaliknya orang yang levelnya tidak mencapai standar, dikatakan sebagai tidak produktif atau kinerja rendah. Penilaian prestasi kerja iidefinisikan sebagai suatu kegiatan untuk menilai rasio hasil, kerja nyata dengan standar, baik kualitas, maupun kuantitas yang dihasilkan setiap individu karyawan (Handoko, 1999).

Mengemukakan bahwa tujuan dari pengukuran prestasi kerja karyawan adalah 1). Perbaikan prestasi kerja; 2). Penyesuaian-penyesuaian kompensasi; 3). Keputusankeputusan penempatan; 4). Kebutuhan-kebutuhan latihan dan pengembangan; 5). Perencanaan dan pengembangan karir; 6). Penyimpangan-penyimpangan proses staffing; 7). Ketidak-akuratan informasional; 8). Kesalahan-kesalahan desain pekerjaan; 9). Kesempatan kerja yang adil; 10). Tantangan-tantangan eksternal (Wankel, 1986). Hasil bahwa variabel yang dominan yang mempengaruhi prestasi kerja karyawan adalah upah atau meningkatkan jumlah gaji atau perbaikan system imbalan, selain upah atau gaji, kondisi kerja, seperti ruang kerja yang nyaman, sirkulasi udara, luas ruangan kerja, peralatan kerja yang lengkap dan fasilitas pemmjang lainnya. Serta faktor kebutuhan sosial seperti kasih sayang serta suasana yang nyaman dan damai dari pihak perusahaan (Natsir, 2003).

Prestasi kerja adalah evaluasi yang sistematis terhadap pekerjaan yang telah dilakukan oleh karyawan dan ditujukan untuk pengembangan (Sikula, 2011). Prestasi kerja adalah prosedur yang formal dilakukan di dalam organisasi untuk mengevaluasi pegawai dan sumbangan serta kepentingan bagi pegawai (Yoder, 1962). Prestasi kerja adalah perbandingan antara persepsi aktual bawahan dengan standar yang ditetapkan dalam langkah 
pertama, melibatkan beberapa jenis bentuk pengharkatan (Dessler, 2009). Prestasi kerja adalah kinerja yang dicapai oleh seseorang karyawan dalam melaksanakan tugas dan pekerjaan yang diberikan kepadanya (Sastrohadiwiryo, 2013). Prestasi kerja biasanya dikaitkan dengan usaha penentuan nilai suatu pekerjaan (Hasibuan, 2015).

\section{Kompetensi}

Kompetensi dapat dijelaskan secara sederhana sebagai kemampuan manusia yang ditemukan dari praktek dunia nyata dapat digunakan untuk membedakan antara mereka yang sukses (superior) dengan yang biasa-biasa saja di tempat kerja (Kennedy, 1995). Kompetensi "an underlying characteristic of individual that is causally related to criterionreferenced effective and'or superior performance in a job or situation" (Spencer, 2001). Sebagai karakteristik individu yang melakukan kompetensi merupakan bagian dari kepribadian individu yang relative dalam dan stabil, dapat dilihat dan diukur dari perilaku individu yang bersangkutan di tempat kerja atau dalam berbagai situasi. Kemampuan professional dan kemainpuan individu seseorang di tempat kerja (Simanjuntak, 2005). Kompetensi adalah kemampuan (ability) atau kapasitas seseorang untuk mengerjakan berbagai tugas dalam suatu pekerjaan, dimana kemampuan ini ditentukan oleh dua faktor yang kemampuan intelektual dan kemampuan fisik (Robbin, 2007). Kompetensi adalah kecapakan yang memadai untuk melakukan suatu tugas atau sebagai memiliki keterampilan dan kecakapan yang diisyratkan (Suparno, 2012).

Kompetensi adalah kekuasaan (kewenangan) untuk menentukan atau memutuskan suatu hal (Poerwadarminta, 1993). Kompetensi adalah sebuah karakteristik manusia yang berhubungan dengan efektifitas performa, karakteristik ini dapat dilihat seperti gaya bertindak, berperilaku, dan berpikir (Looy, et al, 2003). Kompetensi adalah bagian kepribadian yang mendalam dan melekat kepada seseorang serta perilaku yang dapat diprediksi pada berbagai keadaan dan tugas pekerjaan (Mitrani, 2002). Kompetensi adalah faktor mendasar yang dimiliki seseorang yang mempunyai kemampuan lebih, yang membuatnya berbeda dengan seseorang yang mempunyai kemampuan rata-rata atau biasa saja (Mangkunegara, 2005). Kompetensi adalah suatu sifat atau karakteristik yang dibutuhkan oleh seorang pemegang jabatan agar dapat melaksanakan jabatan dengan baik, atau juga dapat berarti karakteristik/ciri-ciri seseorang yang mudah dilihat termasuk pengetahuan, keahlian dan perilaku yang memungkinkan untuk bekerja (Byars dan Rue, 1997). Kompetensi adalah dibagi menjadi 2 yaitu kompetensi dasar (Threshold) dan Komptensi pembeda (differentiating). Kompetensi dasar (Threshold competencies) adalah karakteristik utama, yang biasanya berupa pengetahuan atau keahlian dasar seperti kemampuan untuk membaca. Kompetensi pembeda (differentiating) adalah kompetensi yang membuat seseorang berbeda dari yang lain (Fogg, 2004).

\section{Motivasi}

Abraham Sperling (dalam Mangkunegara, 2005) mengemukakan bahwa motif didefinisikan sebagai suatu kecenderungan untuk beraktivitas, dimulai dari dorongan dalam diri (drive) dan diakhiri dengan penyesuaian diri. Penyesuaian diri dikatakan untuk memuaskan motif. William J. Stanton (dalam Mangkunegara, 2002) mendefinisikan bahwa motif adalah kebutuhan yang distimulasi yang berorientasi kepada tujuan individu dalam mencapai rasa puas. Motivasi didefinisikan oleh Fillmore H. Stanford (dalam Mangkunegara, 2005) bahwa motivasi sebagai suatu kondisi yang menggerakkan manusia ke arah suatu tujuan tertentu. Motivasi seseorang bekerja tergantung pada reward yang diterimanya dan punisment yang akan dialaminya nanti (Ishak \& Hendri, 2003). Herzberg (1998) mengembangkan teori hierarki kebutulian Maslow menjadi teori dua faktor tentang 
motivasi. Dua faktor itu dinamakan faktor pemuas (motivation factor) yang disebut dengan satisfier atau intrinsic motivation dan faktor pemelihara (maintenance factor) yang disebut dengan disatisfier atau extrinsic motivation.

Faktor pemuas yang disebut juga motivator yang merupakan faktor pendorong seseorang untuk berprestasi yang bersumber dari dalam diri seseorang tersebut (kondisi intrinsik) antara lain: 1). Prestasi yang diraih (achievement); 2). Pengakuan orang lain (recognition); 3). Tanggung j awab (responsib ility); 4). Peluang untuk maju (advancement); 5). Kepuasan kerja itu sendiri (the work it self); 6). Kemungkinan pengembangan karir (the possibility of growth).

\section{METODE PENELITIAN}

Data yang digunakan adalah data primer dengan menyebar kuesioner kepada karyawan PT. Multi Pratama Interbuana Indonesia. Metode analisis menggunakan analisis deskrisi dan analisis regresi linear sederhana dan berganda. Sampel yang digunakan sebanyak 59 karyawan dari jumlah populasi 142 karyawan yang diperoleh menggunakan slovin dengan tingkat kesalan 10\%. (Slovin, 2001).

\section{HASIL PENELITIAN DAN PEMBAHASAN}

\section{Hasil Penelitian}

Analisis regresi linear sederhana digunakan untuk mengetahui seberapa besar hubungan kausalitas masing - masing variabel independen terhadap variabel dependen, yaitu pengaruh kompetensi terhadp kinerja karyawan dan pengaruh motivasi terhadap prestasi kerja.

Tabel 1: Pengaruh Kompetensi terhadap Prestasi Kerja PT. Multi Pratama Interbuana Indonesia

\begin{tabular}{cccccc}
\hline \multirow{2}{*}{ Variabel } & \multicolumn{5}{c}{ Parameter } \\
\cline { 2 - 6 } & R Square & Konstanta & Koef. B & Sig & a \\
\hline Kompetensi & 0.828 & 4.293 & 0.687 & 0.000 & 0.05 \\
\hline
\end{tabular}

Keterangan : Varibel Prestasi Kerja

Sumber: Data diolah 2020

Berdasarkan Tabel 1, nilai koefisien determinasi $\left(\mathrm{R}^{2}\right)$ sebesar 0,828 , artinya kontribusi kompetensi kepada prestasi kerja sebesar $82,8 \%$, sedangkan sisanya $17,2 \%$ disumbangkan oleh faktor lain. Hasil analisis diperoleh persamaan regresi linear sederhana sebagai berikut: $\mathrm{Y}=4,293+0,687 \mathrm{X}_{1}$. Koefisien regresi kepuasan kerja sebesar 0,687, hal ini menunjukkan bahwa jika ada kenaikan kompetensi, maka akan menyebabkan kenaikan prestasi kerja.

Tabel 2: Pengaruh Motivasi terhadap Prestasi Kerja PT. Multi Pratama Interbuana Indonesia

\begin{tabular}{llllll}
\hline \multirow{2}{*}{ Variabel } & \multicolumn{4}{c}{ Parameter } \\
\cline { 2 - 5 } & R Square & Konstanta & Koef. B & Sig & a \\
\hline
\end{tabular}




\begin{tabular}{llllll}
\hline Motivasi & 0.828 & 5.456 & 0.502 & 0.000 & 0.05 \\
\hline
\end{tabular}

Keterangan : Varibel Prestasi Kerja

Sumber: Data diolah 2020

Berdasarkan Tabel 2, nilai koefisien determinasi $\left(\mathrm{R}^{2}\right)$ sebesar 0,828 , artinya kontribusi motivasi kepada prestasi kerja sebesar $82,8 \%$, sedangkan sisanya 17,2\% disumbangkan oleh faktor lain. Hasil analisis diperoleh persamaan regresi linear sederhana sebagai berikut: $\mathrm{Y}=$ $5,456+0,502 X_{1}$. Koefisien regresi kepuasan kerja sebesar 0,502, hal ini menunjukkan bahwa jika ada kenaikan motivasi, maka akan menyebabkan kenaikan prestasi kerja.

Tabel 3: Pengaruh Kompetensi dan Motivasi terhadap Prestasi
Kerja PT. Multi Pratama Interbuana Indonesia
\begin{tabular}{lccccc}
\multicolumn{5}{c}{ Parameter } \\
\hline \multirow{2}{*}{ Variabel } & \multirow{5}{*}{ R Square } & Konstanta & Koef. B & Sig & a \\
\hline Kompetensi & \multirow{2}{*}{0.892} & \multirow{2}{*}{4.021} & 0.787 & 0.000 & \multirow{2}{*}{0.05} \\
Motivasi & & & 0.432 & 0.002 & \\
\hline Pengujian Signifikansi & & & & \\
\hline F hitung = 102.254 & & & \\
\hline
\end{tabular}
Keterangan : Varibel Prestasi Kerja
Sumber: Data diolah 2020

Berdasarkan Tabel 3, hasil analisis diperoleh nilai F-hitung sebesar 102,254,hal ini dapat diartikan bahwa secara bersama-sama kepuasan kompetensi dan motivasi berpengaruh terhadap prestasi kerja. Koefisien determinasi $\left(\mathrm{R}^{2}\right)$ sebesar 0,892 yang artinya bahwa kontribusi kompetensi dan motivasi terhadap prestasi sebesar $89,2 \%$, sedangkan sisanya 10,8\% disumbangkan oleh faktor lain.

Persamaan linear berganda dapat dituliskan sebagai berikut: $\mathrm{Y}=4,021+0,787 \mathrm{X}_{1}+$ $0,432 \mathrm{X}_{2}$, Koefisien kompetensi dan motivasi bertanda prositif dan signifikan terhadap prestasi kerja. Koefisien kompetensi sebesar 0,787, artinya jika ada kenaikan kompetensi, maka akan meningkatkan prestasi kerja atau sebaliknya dengan asumsi motivasi sebesar 0,432, artinya jika ada kenaikan motivasi maka akan meningkatkan prestasi kerja atau sebaliknya dengan asumsi kompetensi tetap.

\section{Pembahasan}

\section{Pengaruh Kompetensi Terhadap Prestasi Kerja}

Hasil penelitian menunjukan bahwa kompetensi mendorong peningkatan prestasi kerja karyawan PT. Multi Pratama Interbuana Indonesia. Hal ini menunjukkan bahwa karyawan memiliki pengetahuan yang mendukung pekerjaan, memiliki kemauan untuk meningkatkan pengetahuan, memiliki keahlian teknis sesuai bidang pekerjaan, memiliki kemampuan mengidentifikasi masalah, memiliki inisiatif membentu rekan kerja, ramah dalam melakanakan pekerjaa. Hasil penelitian ini sejalan dengan penelitian yang dilakukan oleh Aprilda, (2012), dan Fahrunisya, (2014) yang menyatakan bahwa kompetensi berpengaruh signifikan terhadap prestasi kerja karyawan.

\section{Pengaruh Motivasi Terhadap Prestasi Kerja}

Hasil penelitian menyatakan bahwa motivasi mendorong peningkatan prestasi kerja karyawan PT. Multi Pratama Interbuana Indonesia. Hal ini menunjukkan bahwa gaji yang diterima karyawan sudah sesuai dengan ketentuan, kemudian mendapat bonus tahunan, adanya tunjangan kesehatan, dalam bekerja selalu menggunakan perlengkapan kerja, adanya 
pengakuan dari pimpinan atas prestasi kerja, dan mendapatkan penghargaan berdasarkan kemampuan kerja, karyawan bekerja selalu mengerahkan kemampuannya, dan perusahaan selalu memberikan pelatihan pada karyawan untuk meningkatkan prestasi kerjanya. Hasil penelitian ini sejalan dengan hasil penelitian yang dilakukan Sina, et al, (2015) dan Cahyono, et, al (2013) yang menyatakan bahwa motivasi berpengaruh signifikan terhadap prestasi kerja karyawan.

\section{Pengaruh Kompetensi dan Motivasi Terhadap Prestasi Kerja}

Berdasarkan hasil analisis diketahui bahwa kompetensi dan motivasi mendorong peningkatan prestasi kerja karyawan PT. Multi Pratama Interbuana Indonesia. Hasil penelitian ini sama dengan hasil penelitian yang dilakukan Purnama dan Kempa, (2016), Yuningsih dan Ardianti, (2019), Yuliana, (2017) yang menyatakan bahwa kompetensi dan motivasi berpengaruh terhadap prestasi kerja karyawan.

\section{KESIMPULAN DAN SARAN}

\section{Kesimpulan}

1. Kompentesi dan motivasi secara bersamaan-sama mendorong peningkatan pengaruh terhadap prestasi kerja.

2. Motivasi memberikan dukungan yang relatif tinggi terhadap prestasi kerja jika dibandingkan dengan kompetensi.

\section{Saran}

1. Perlu diusahakan untuk mengkaji ulang kebijakan kompetensi yang sesuai dengan mekanisme kerja hal ini dapat dilakukan dengan pembuatan standard kompetensi yang terintergretide dengan system manajemen perusahaan yang berorientasikan pada visi dan misi perusahaan.

2. Kebijaksanaan pemberian motivasi terhadap karyawan sudah baik, namun belum optimal oleh sebab itu perlu di review kembali atau dikaji ulang kebijakan pemberian motivasi yang diberikan dengan beberapa cara dan model serta perlu dilakukan penerapan metode metode baru dalam pemberi motivasi.

3. Perlu diusulkan untuk membuat ulang system operation prosedur (SOP) yang selama ini dilakukan dengan cara melakukan mengganti atau revisi perintah dan petunjuk kerja yang sudah tidak relavan serta selalu melakukan improvement disegala sektor di perusahaan.

\section{DAFTAR PUSTAKA}

Aprilda, A. 2012. Pengaruh Kompetensi Terhadap Prestasi Kerja Pegawai (Studi pada Bagian Pengelolaan Keuangan Balai Pengembangan Pendidikan Nonformal dan Informal Regional I Medan). Jurnal Administrasi Publik. Vol. 3 No. 2. Hal 181-206. ISSN: 2088-527X.

Byars dan Rue. 1997. Managing Human Resources: Productivity, Quality Work of Life. Profit. Fourth Edition New York: McGraw-Hill, Inc.

Cahyono, Puguh Dwi., Hamid, Djamhur dan Mukzam, Moch. Djudi. 2013. Pengaruh Motivasi Terhadap Prestasi Kerja Karyawan (Studi pada Karyawan AJB Bumi Putera 1912 Cabang Kayutangan Malang. Jurnal Administrasi Bisnis. Vol. 4 No. 1. 2013. Hal. 1-7. 
David C. McClelland. 1997. Testing for Competence Rather Than Inteligence. New Jersey. Prentice-Hall.Inc. A Pearson Company.

Dessler, Gary, 2009, Manajemen SDM : buku 1. Jakarta: Indeks

Fahrunisya, Nova. 2014. Pengaruh Kompetensi Karyawan Terhadap Prestasi Kerja Karyawan Pada Direktorat HRD Dan General Affair di PT. Cipaganti Group Bandung. Skripsi. Universitas Islam Bandung.

Fogg, M. 2004. The Greatest Networker in the Workd. New York: The Three Rivers Press. Foster, Bill. 2001. Managing Human Resources : Productivity, Quality of Work Life, Profit, Singapore. McGraw-Hill international Editors.

Handoko. T. Hani. 1999. Management Personalia dan Sumber Daya Manusia. Yogyakarta: BPFE.

Hasibuan, Malayu SP. 2015. Manajemen Sumber Daya Manusia. Jakarta: PT Bumi Aksara. Herzberg. F., 1995. Essentials of Human Resource Management, New Jersey. PrenticeHall.Inc. A Pearson Company.

Ishak. Arep \& Hendry. 2003. Tanjung. Manajemen Motivasi. Jakarta: Gremedia Widiasarana.

Kennedy P., 1995. Managing Organizational Behavior. Fourth Edition. United States. John Wiley and Sons Inc.

Looy, Bart Van, Paul Gemmel and Roland Van Dierdonck. 2003. 2nd Edition. Service Management. Prentice Hall

Mangkunegara .A.A. Anwar Prabu. 2005. Manajemen Sumber Daya Manusia Perusahaan. Bandung: Remaja Rosdakarya Offset.

Mitrani, Alain. 2002. Manajemen Sumber Daya Manusia Berbasis Kompetensi (Terjemahan). Jakarta: PT. Intermasa.

Natsir, Moch. 2003. Manajemen Sumher Daya Manusia. Jakarta: Raja Grafindo Persada.

Simanjuntak, Payaman. 2005. Manajemen dan Evaluasi Kinerja, Fakultas Ekonomi Universitas Indonesia, Jakarta.

Poerwadarminta, W.J.S. 1193. Kamus Umum Bahasa Indonesia. Edisi Ketiga. Jakarta: Balai Pustaka.

Robbins, P. Stephen. 2007. Perilaku Organisasi. Edisi Sepuluh. Diterjemahkan oleh: Benyamin Molan. Jakarta: Erlangga.

Rosyadi dan Muwarti. 2002. Teori Pengembangan Organisasi. Jakarta: Sinar Bumi Aksara. Sastrohadiwiryo, B. Siswanto. 2013. Manajemen Tenaga Kerja Indonesia Pendekatan Administrasi dan Operasional. Jakarta: Bumi Aksara

Sikula, Andrew E. 2011. Manajemen Sumber Daya Manusia. Bandung: Erlangga.

Sina, Ibnu., Kusuma, Aji Ratna dan Paronoan, DB. 2015. Pengaruh Motivasi Terhadap Prestasi Kerja Pada Pegawai Dinas Bina Marga Dan Pengairan Kota Samarinda. Jurnal Administrative Reform, Vol. 3 No. 1, Januari-Maret 2105. Hal. 210-221.

Slovin. 2001. Sampling : A Quick Reliable Guide to Practical Statistics. New York. Simon and Schuster.

Suparno, A. Suhaenah. 2012. Membangun Kompetensi Belajar. Direktorat Jendral Pendidikan Tinggi Departemen Pendidikan Nasional.

Vroom. 1991. Human Resource Development, alih bahasa M. As'ad. Jakarta. Gramedia.

Wankel, Carles. 1986. Fundamental of Management. Texas. Business Publication.

Yoder, Dale. 1962. Personal Principles and Policies. Printice Hall Inc, Maruzen Company Ltd, Second Edition.

Yuliana. 2017. Pengaruh Kompetensi dan Motivasi Kerja Terhadap Kinerja Karyawan Perusahaan Pada PT Haluan Star Logistic. Jurnal Ilmiah Manajemen Bisnis, Vol. 17 No. 2, Juli-Desember 2017. Hal. 135-150. 
Yuningsih, Erni dan Ardianti. 2019. Pengaruh Kompetensi dan Motivasi Terhadap Kinerja Pegawai Pada PT XXX. Jurnal Visionida, Volume 5 Nomor 1 Juni 2019. Hal. 32-45. 